\title{
Perancangan Sistem Informasi Berbasis Web untuk Pengendalian Pelayanan di Balai Pengembangan Teknologi Tepat Guna Yogyakarta
}

\author{
Heriyanto Susilo ${ }^{1}$, B. Laksito Purnomo ${ }^{1 *}$, Anugrah K. Pamosoaji ${ }^{1}$, Lenny Halim ${ }^{1}$, Parama \\ Kartika Dewa ${ }^{1}$ \\ 1) Departemen Teknik Industri, Fakultas Teknologi Industri, Universitas Atma Jaya Yogyakarta \\ Jl. Babarsari No. 43 Yogyakarta 55281, Indonesia \\ Email: laks.purnomo@uajy.ac.id
}

\begin{abstract}
ABSTRAK
Pada paper ini dibahas solusi rekapitulasi data berbasis digital yang diterapkan pada Balai Pengembangan Teknologi Tepat Guna (BPTTG) Daerah Istimewa Yogyakarta (DIY). BPTTG DIY merupakan sebuah sebuah instansi pembina teknis yang bergerak di bidang teknologi rekayasa yang berada di bawah Dinas Perindustrian dan Perdagangan Pemda DIY. Beberapa layanan yang diberikan oleh lembaga ini antara lain: layanan konsultasi \& informasi Alat Tepat Guna (ATG), layanan rekayasa \& produksi ATG, layanan perbengkelan, dan layanan Common Fasilities Small and Medium Industry (CFSMI) kemasan. Lembaga ini juga memiliki dua seksi yaitu seksi rekayasa dan produksi dan seksi pengembangan dan layanan kemasan dan produk kulit. Kedua seksi ini memiliki kantor dan workshop yang terpisah secara geografis. Kondisi ini menimbulkan dampak negatif pada proses dokumentasi kegiatan yang masih dilakukan secara manual, diantaranya adalah lambatnya proses dokumentasi, potensi kehilangan dokumen, dan kesalahan pencatatan. Solusi yang dikembangkan adalah sebuah sistem informasi yang mampu mempercepat pelaporan layanan dari setiap seksi ke kantor BPTTG sehingga pelayanan yang dilakukan setiap seksi dapat dimonitor secara berkala. Perancangan solusi menggunakan pendekatan Rapid Application Development (RAD). Sistem informasi dirancang dalam bentuk website sehingga dapat diakses melalui web browser dan tidak diperlukan adanya instalasi di setiap komputer.
\end{abstract}

Kata kunci: sistem informasi, proses bisnis, Rapid Application Development (RAD), web-based, digitalisasi.

\section{ABSTRACT}

This paper discusses a digital-based data recapitulation solution that is applied to the Center for Appropriate Technology Development / Pengembangan Teknologi Tepat Guna (BPTTG) of the Special Region of Yogyakarta (DIY). BPTTG DIY is a technical advisory agency engaged in engineering technology under the Department of Industry and Trade of the DIY Regional Government. Some of the services provided by this institution include: Appropriate Tools/Alat Tepat Guna (ATG) consulting \& information services, ATG engineering \& production services, workshop services, and Common Facilities Small and Medium Industry (CFSMI) packaging services. The institute also has two sections, namely the engineering and production section and the packaging and leather product development and service section. These two sections have geographically separated offices and workshops. This condition has a negative impact on the documentation process of activities that are still carried out manually, including the slow documentation process, potential loss of documents, and recording errors. The solution developed is an information system that is able to speed up service reporting from each section to the BPTTG office so that the services performed by each section can be monitored regularly. The design of the solution uses the Rapid Application Development (RAD) approach. The designed web-based information system allow easy access via a web browser and no installation is required on every computer.

Keywords: information systems, business process, Rapid Application Development (RAD), web-based, digitalization. 


\section{Pendahuluan}

Dokumentasi adalah salah satu bagian dari aktivitas manajemen informasi pada institusi modern. Tujuan utamanya adalah menciptakan sistem pengelolaan informasi sehingga informasi tersebut menjadi lebih kredibel. Kredibilitas informasi penting karena menentukan tingkat kepercayaan publik terhadap perusahaan (McKnight \& Keller, 2009; Li \& Suh, 2015). Salah satu masalah dalam mencapai kredibilitas informasi adalah ketidakakuratan ketika melakukan pencatatan atau penginputan data.

Kebutuhan akan dokumentasi juga dirasakan oleh Balai Pengembangan Teknologi Tepat Guna (BPTTG) Daerah Istimewa Yogyakarta (DIY). BPTTG merupakan sebuah instansi pembina teknis yang bergerak di bidang teknologi rekayasa yang berada di bawah Dinas Perindustrian dan Perdagangan Pemda DIY. Visi organisasi BPTTG adalah "mewujudkan alat tepat guna sebagai sarana peningkatan kualitas dan kapasitas produksi Industri Kecil dan Menengah (IKM) untuk peningkatan daya saing untuk kesejahteraan IKM." Beberapa layanan yang ditawarkan antara lain: layanan konsultasi \& informasi Alat Tepat Guna (ATG), rekayasa \& produksi ATG, perbengkelan, dan Common Fasilities Small and Medium Industry (CFSMI) kemasan. Seluruh biaya layanan yang terdapat di BPTTG telah diatur dalam Peraturan Gubernur Daerah Istimewa Yogyakarta.

BPTTG terdiri atas dua seksi, yaitu seksi rekayasa dan produksi (selanjutnya disebut seksi rekayasa) dan seksi pengembangan dan layanan kemasan dan produk kulit (selanjutnya disebut seksi kemasan). Kedua seksi melingkupi beberapa unit pelayanan terpadu (UPT). Struktur seperti ini sejalan dengan penerapan organisasi yang minim struktur dan kaya fungsi. Seksi kemasan melakukan pekerjaan yang berkaitan dengan produksi kemasan. Seksi kemasan berlokasi di Jalan Laksda Adisucipto KM. 8,5. Seksi rekayasa melakukan pekerjaan yang berkaitan dengan pengolahan alat-alat dari logam, metal, perak, dan kayu. Kantor dan bengkel seksi rekayasa terletak di lokasi yang sama dengan kantor BPTTG yaitu di Jalan Kusumanegara nomor 186. Seksi rekayasa memiliki bengkel lain yang terletak di Jalan Sekarsuli.

Kebutuhan akan pelaporan dari setiap seksi kepada Kepala BPTTG meningkat seiring dengan semakin kompleksnya pekerjaan yang dilakukan setiap seksi. Masalah utama yang dihadapi dalam setiap sesi pelaporan adalah tidak akuratnya pendokumentasian data dari setiap seksi. Akibatnya, BPTTG mengalami kesulitan menggambarkan kondisi semua seksi dan ada potensi terjadi pengambilan keputusan yang salah atau tidak tepat sasaran. Menurut survei yang dilakukan, ketidakakuratan ini disebabkan oleh metode pencatatan yang dilakukan secara manual.

Berdasarkan penelusuran literatur yang telah dilakukan, pencatatan manual memang menjadi salah satu sebab utama terjadinya ketidakakuratan data di berbagai area. Dalam studi yang dilakukan oleh Famsila (2016) dan Rakasiwi (2018) di area retail, ketidakakuratan ini terjadi pada proses yang membutuhkan lead time yang pendek seperti penjualan, pembelian, dan retur pembelian. Deo (2019), yang melakukan studi di perusahaan jasa, juga menghadapi permasalahan yang sama pada perhitungan biaya jasa. Selain disebabkan pencatatan yang dilakukan secara manual yang membuat faktor manusia memiliki pengaruh yang cukup signifikan, masalah lainnya adalah kompleksitas pendataan item-item yang tidak cukup rapi (Ikhlas, 2018). Keterbatasan kemampuan manusia dalam merekapitulasi data-data berukuran besar dan berstruktur kompleks memberikan kontribusi pada peningkatan level ketidakakuratan tersebut. Tuntutan untuk merekapitulasi dan melaporkan data dalam waktu singkat juga dihadapi pada studi yang dilakukan oleh Nazir \& Darmawati (2018) di area inventory.

Masalah ketidakakuratan data yang disebabkan pencatatan manual dapat diatasi dengan implementasi sistem informasi (Hakim dan Fitriani, 2016, Famsila, 2016; Rakasiwi, 2018; Irnawati dan Listianto, 2018; Deo, 2019). Penerapan sistem informasi terbukti mampu mengatasi masalahmasalah tersebut. Setidaknya ada dua macam framework yang diimplementasikan. Pertama, framework berbasis aplikasi komputer desktop (Famsila, 2016; Rakasiwi, 2018; Deo, 2018; Nazir dan Darmawati, 2018). Kedua, framework berbasis web (Irnawati \& Listianto, 2018). Framework berbasis web memiliki keunggulan dibandingkan dengan berbasis aplikasi komputer desktop, salah satunya adalah tingkat aksesibilitasnya yang lebih tinggi. Namun, arsitektur jaringannya lebih kompleks karena harus melibatkan server yang biasanya dikelola oleh provider eksternal.

Penelitian ini memberikan solusi pengembangan sistem informasi berbasis web menggunakan pendekatan Rapid Application Development (RAD) seperti yang dilakukan oleh Irnawati \& Listianto 
(2018), Hamzah, dkk. (2019), dan Meiryani \& Sudrajat (2019). Seperti diperlihatkan pada Gambar 2, tahapan pada model RAD ada 4 langkah, yaitu perencanaan kebutuhan, desain pengguna, kontruksi, dan cutover (Tilley dan Rosenblatt, 2017). Tahapan ini lebih pendek daripada SDLC yang terdiri atas 5 langkah (penyusunan kebutuhan, desain, implementasi, verifikasi, perawatan). Perancangan sistem informasi dilakukan berdasarkan model Rapid Application Development (RAD). Menurut Maheswari \& Jain (2012) dalam Hamzah dkk. (2019), keunggulan pendekatan RAD adalah bahwa pendekatan ini mempercepat penyelesaian proyek. Hal ini disebabkan tahapan proyek pengembangan menjadi lebih pendek (Delima dkk. 2017 dalam Hamzah dkk. 2019). Seperti diperlihatkan pada Gambar 2, tahapan pada model RAD ada 4 langkah, yaitu perencanaan kebutuhan, desain pengguna, kontruksi, dan cutover (Tilley dan Rosenblatt, 2017). Tahapan ini lebih pendek daripada Software Development Life Cycle yang terdiri atas 5 langkah (penyusunan kebutuhan, desain, implementasi, verifikasi, perawatan).

\section{Metodologi}

Penelitian ini melalui beberapa tahapan yang dimulai dari penentuan objek penelitian, penentuan latar belakang dan rumusan masalah, penentuan tujuan penelitian dan batasan masalah, studi pustaka, pengumpulan data, perancangan sistem informasi, dan penarikan kesimpulan. Metodologi penelitian ditunjukkan pada Gambar 1.

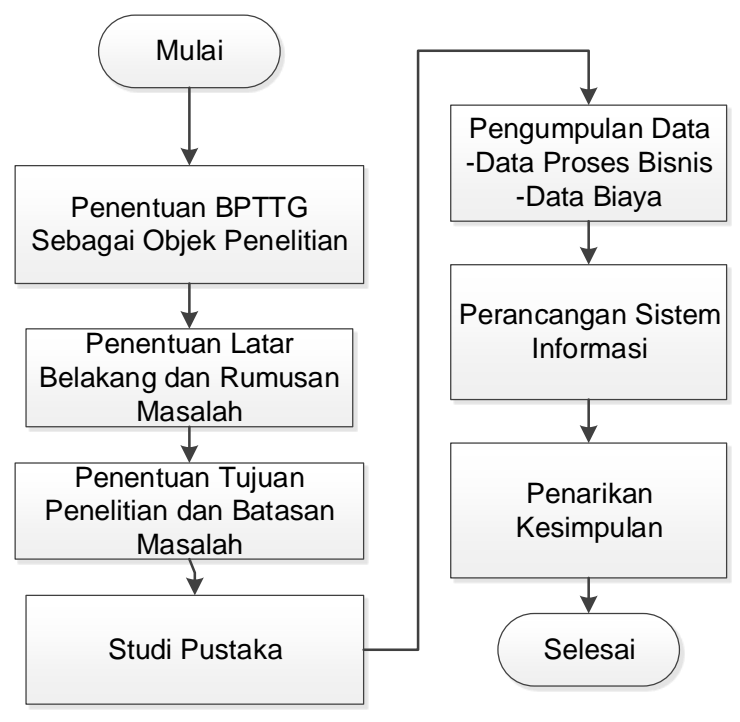

Gambar 1. Metodologi Penelitian

\subsection{Pengumpulan Data}

Pengumpulan data dilakukan dengan wawancara dan pengamatan pelayanan di BPTTG dan dilanjutkan dengan pemetaan proses bisnis. Pemetaan proses bisnis memilki tahapan yaitu (Jacka \& Keller, 2009).

(1) Identifikasi proses

Suatu proses terjadi karena adanya pemicu (trigger) yang menyebabkan proses tersebut dimulai. Kejadian pemicu biasanya meruapakan kejadian yang disebabkan karena kontak dengan pelanggan. Selain mengidentifikasi kejadian pemicu, perlu dilakukan pemetaan terhadap proses-proses yang penting bagi pelanggan.

(2) Pengumpulan informasi

Pengumpulan informasi diawali dengan identifikasi orang atau entitas yang dapat memberikan suatu informasi. Informasi yang dibutuhkan yaitu: urutan proses, pemilik proses, dan kriteria kesuksesan suatu proses.

(3) Wawancara 
Wawancara merupakan aktivitas penting dalam pemetaan proses bisnis. Pemetaan proses bisnis harus mendapat dukungan dari manajemen puncak dan pemilik proses. Manajemen puncak dan pemilik proses merupakan orang yang paling memahami proses bisnis yang dilakukan.

(4) Pembuatan peta proses bisnis

Proses bisnis dipetakan setelah informasi terkait proses bisnis selesai dikumpulkan. Pemetaan dapat dilakukan dengan menggunakan simbol-simbol untuk mempermudah pemahaman.

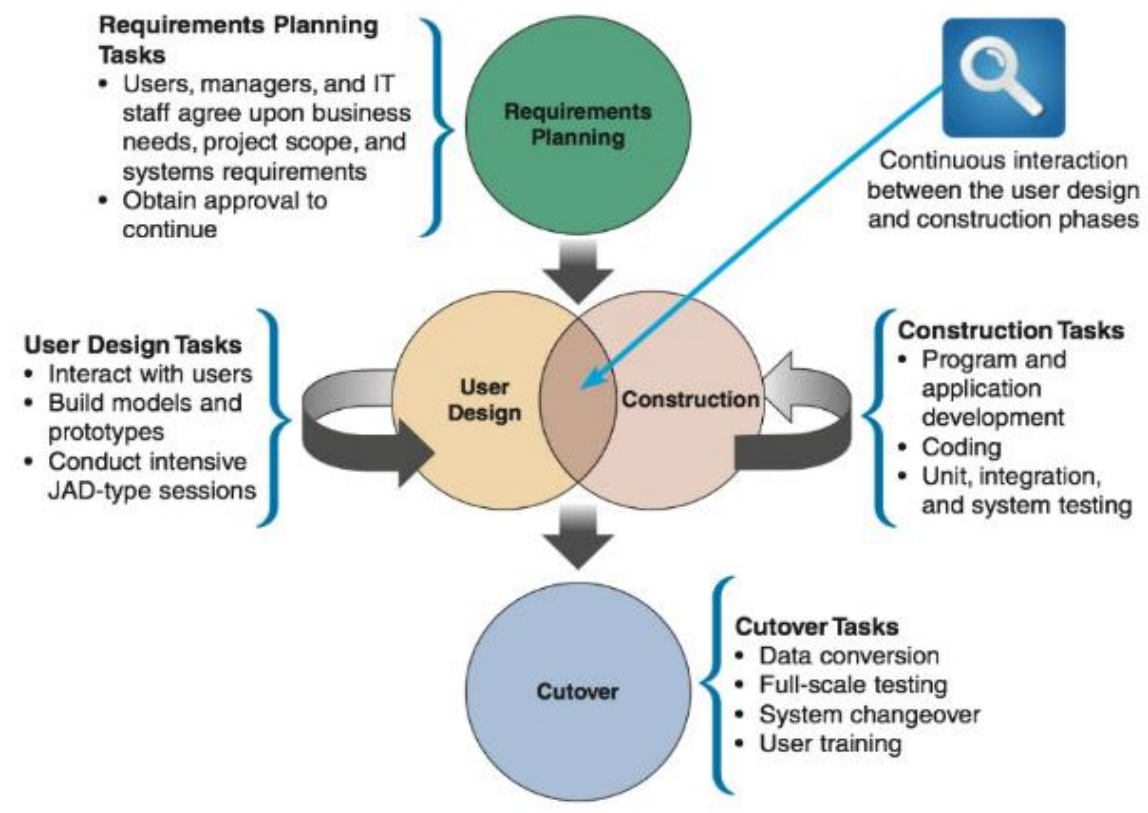

Gambar 2. Model Rapid Application Development (RAD)

\subsection{Perancangan Sistem Informasi}

\subsubsection{Perancangan Kebutuhan}

Pada tahap perencanaan kebutuhan dilakukan pemetaan terhadap proses bisnis yang terjadi di BPTTG, identifikasi terhadap kelemahan proses bisnis saat ini dan pemuatan proses bisnis usulan untuk mengatasi kelemahan proses bisnis saat ini. Tahapan perancangan sistem informasi dapat dilihat pada Gambar 3. Proses yang terjadi digambarkan ke dalam diagram untuk memudahkan perancangan sistem informasi. Diagram yang digunakan yaitu:

(1) Diagram Dekomposisi

Diagram dekomposisi fungsional merupakan representasi dari suatu fungsi atau proses. Prinsip kerja diagram dekomposisi adalah memecah sistem yang kompleks menjadi beberapa modul yang lebih terperinci. Diagram dekomposisi digunakan untuk menunjukkan fungsi bisnis dan memecahnya menjadi fungsi dan proses dengan tingkat yang lebih rendah.

(2) Data Flow Diagram (DFD)

Data flow diagram (DFD) menggunakan simbol untuk menunjukkan aliran data antarentitas, aktivitas pemrosesan, dan elemen penyimpanan data dari suatu sistem (O’Brien \& Marakas, 2010). Entitas harus selalu menjadi pemasok data dalam mewakili catatan yang digunakan dalam setiap proses.

(3) Entity Relationship Diagram (ERD)

ERD merupakan diagram yang digunakan untuk menunjukkan hubungan atau relasi antarentitas yang ada dalam sebuah sistem. Terdapat tiga jenis komponen yang menyusuh sebuah ERD, antara lain:

i.Entitas (objek untuk menyimpan data: orang, tempat, objek, kejadian, atau organisasi)

ii. Atribut (obyek untuk mengidentifikasi suatu entitas). 
iii. Relasi (hubungan antara satu atau lebih entitas dalam suatu sistem)

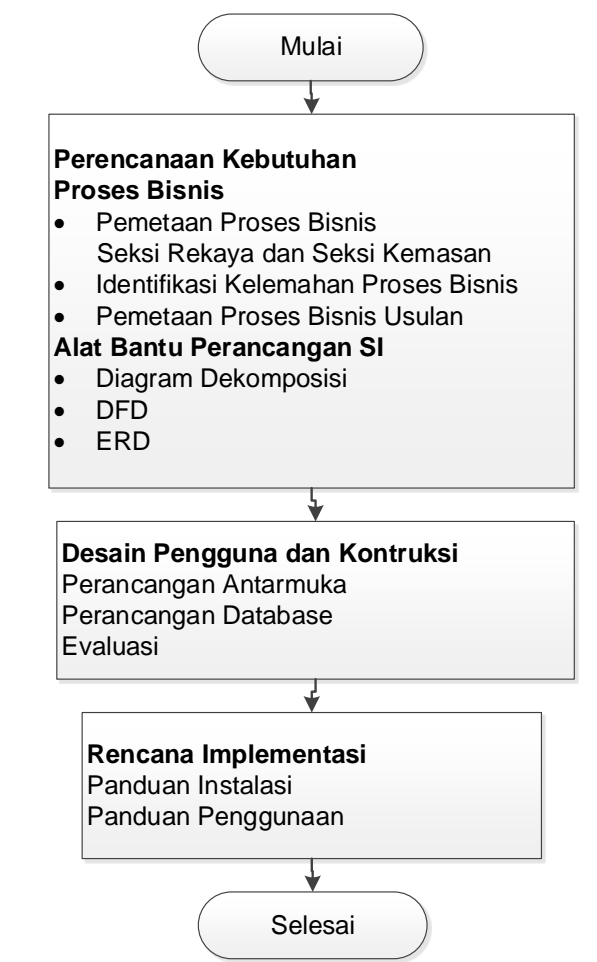

Gambar 3. Tahapan Perancangan Sistem Informasi

\subsubsection{Desain Pengguna dan Konstruksi}

(1) Perancangan Antarmuka

Perancangan antarmuka dikembangkan dari tema SB Admin 2 yang dibangun menggunakan Bootsrap 4. Bootsrap merupakan sebuah framework open-source yang berfungsi untuk mempermudah pengembangan front-end dari sebuah web. Perancangan back-end dikembangkan dengan bantuan framework Codelgniter 3. Bahasa pemrograman yang digunakan adalah PHP. PHP menggunakan sistem server-side. Server-side programming merupakan bahasa pemrograman yang script atau programnya akan diproses di dalam server. Penggunaan PHP menyebabkan web dapat dibuat dinamis sehingga maintenance situs web tersebut menjadi lebih mudah dan efisien.

\section{(2) Perancangan Database}

Perancangan sistem informasi dilakukan dengan menggunakan MySQL sebagai database. MySQL merupakan salah satu jenis database server yang umum digunakan. MySQL merupakan sebuah software sistem manajemen database SQL yang bersifat multithread dan multiuser. MySQL dapat dijalankan pada berbagai sistem operasi seperti linux, windows, Mac Os, dan beberapa sistem operasi lainnya. Pengelolaan database dilakukan menggunakan bantuan aplikasi web phpMyAdmin.

\subsubsection{Rencana Implementasi}

(1) Panduan Instalasi

Panduan instalasi berisikan panduan mengenai cara instalasi sistem informasi agar siap untuk digunakan. Terdapat dua panduan instalasi yaitu panduan instalasi menggunakan server lokal (localhost) dan hosting ke server online.

(2) Panduan Penggunaan

Panduan penggunaan sistem Informasi dibuat untuk memudahkan pengguna dalam mengoperasikan sistem informasi. Panduan penggunaan berisikan penjelasan terkait menu-menu yang terdapat dalam sistem informasi 


\section{Hasil}

\subsection{Proses Bisnis Seksi Rekayasa}

Berdasarkan hasil wawancara dan pengamatan, dilakukan pemetaan proses bisnis dan dilanjutkan dengan identifikasi kelemahan atau permasalahan pada proses bisnis saat ini. Terdapat empat permasalahan yaitu penulisan informasi yang tidak lengkap, tidak adanya pelaporan status pengerjaan, berkas hilang, dan penyerahan berkas \& pelaporan layanan yang dilakukan setiap satu bulan. Identifikasi kelemahan proses bisnis ditunjukkan pada Tabel 1 dan untuk mengatasi permasalahan tersebut diberikan usulan perbaikan yang ditunjukkan pada Tabel 2.

Tabel 1. Identifikasi Kelemahan Proses Bisnis Seksi Rekayasa

\begin{tabular}{|l|l|l|}
\hline \multicolumn{1}{|c|}{ Aktivitas } & \multicolumn{1}{|c|}{ Permasalahan } & \multicolumn{1}{c|}{ Dampak } \\
\hline $\begin{array}{l}\text { Membuat Surat Perintah Kerja } \\
\text { (SPK) dan Bon Material }\end{array}$ & $\begin{array}{l}\text { Penulisan informasi yang tidak } \\
\text { lengkap. }\end{array}$ & Kesulitan ketika melakukan evaluasi. \\
\hline Melakukan pekerjaan sesuai SPK & $\begin{array}{l}\text { Tidak ada pelaporan status } \\
\text { pengerjaan dari operator. }\end{array}$ & $\begin{array}{l}\text { Tidak dapat memberikan informasi } \\
\text { status pengerjaan kepada customer. }\end{array}$ \\
\hline $\begin{array}{l}\text { Mengarsip Blanko Layanan, SPK, } \\
\text { dan SKR }\end{array}$ & Berkas hilang. & $\begin{array}{l}\text { Tidak ada back-up data jika berkas } \\
\text { hilang sehingga arsip menjadi tidak } \\
\text { lengkap. }\end{array}$ \\
\hline $\begin{array}{l}\text { Menyerahkan Blanko Layanan, } \\
\text { SPK, dan SKR }\end{array}$ & $\begin{array}{l}\text { Penyerahan berkas dan } \\
\text { pelaporan layanan dilakukan } \\
\text { dalam setiap 1 bulan. }\end{array}$ & $\begin{array}{l}\text { Jumlah pelayanan yang dilakukan } \\
\text { setiap seksi baru dapat diketahui } \\
\text { pada saat pelaporan. }\end{array}$ \\
\hline
\end{tabular}

Tabel 2. Usulan Perbaikan Proses Bisnis Seksi Rekayasa

\begin{tabular}{|l|l|l|}
\hline \multicolumn{1}{|c|}{ Permasalahan } & \multicolumn{1}{c|}{ Usulan } & \multicolumn{1}{c|}{ Dampak } \\
\hline $\begin{array}{l}\text { Penulisan informasi yang tidak } \\
\text { lengkap. }\end{array}$ & $\begin{array}{l}\text { Pengisian form pada sistem } \\
\text { informasi menggunakan fitur } \\
\text { "wajib diisi" }\end{array}$ & Kelengkapan informasi. \\
\hline $\begin{array}{l}\text { Tidak ada pelaporan status } \\
\text { pengerjaan dari operator. }\end{array}$ & $\begin{array}{l}\text { Status pengerjaan dilaporkan dan } \\
\text { di-update setiap hari. }\end{array}$ & $\begin{array}{l}\text { Status pengerjaan dapat } \\
\text { diinformasikan kepada } \\
\text { customer. }\end{array}$ \\
\hline Berkas hilang. & $\begin{array}{l}\text { Pembuatan basis data secara } \\
\text { online. }\end{array}$ & Back-up data jika berkas hilang. \\
\hline $\begin{array}{l}\text { Penyerahan arsip dan pelaporan } \\
\text { layanan dilakukan dalam setiap 1 } \\
\text { bulan. }\end{array}$ & $\begin{array}{l}\text { Input data pelayanan dan status } \\
\text { pengerjaan secara online }\end{array}$ & $\begin{array}{l}\text { Data pelayanan dan status } \\
\text { pengerjaan setiap seksi dapat } \\
\text { diterima dalam waktu yang } \\
\text { lebih cepat. }\end{array}$ \\
\hline
\end{tabular}

\subsection{Proses Bisnis Seksi Kemasan}

Terdapat perbedaan dalam proses bisnis seksi rekayasa dan seksi kemasan karena perbedaan layanan yang dilakukan tiap seksi. Pemetaan proses bisnis dilanjutkan dengan identifikasi kelemahan atau permasalahan pada proses bisnis saat ini. Terdapat empat permasalahan, yaitu: penulisan informasi yang tidak lengkap, tidak adanya pelaporan status pengerjaan, berkas hilang, dan penyerahan berkas \& pelaporan layanan yang dilakukan setiap satu bulan. Identifikasi kelemahan proses bisnis ditunjukkan pada Tabel 3 dan untuk mengatasi permasalahan tersebut diberikan usulan perbaikan yang ditunjukkan pada Tabel 4.

Terdapat 4 usulan perbaikan, yaitu: pengisian form pada sistem informasi menggunakan fitur "wajib diisi" , status pengerjaan dilaporkan dan di-update setiap hari, pembuatan basis data secara online dan input data pelayanan dan status pengerjaan secara online. Berdasarkan usulan perbaikan, dilanjutkan dengan pembuatan proses bisnis usulan untuk seksi kemasan. 
Tabel 3. Identifikasi Kelemahan Proses Bisnis Seksi Kemasan

\begin{tabular}{|l|l|l|}
\hline \multicolumn{2}{|c|}{ Aktivitas } & \multicolumn{1}{|c|}{ Permasalahan } \\
\hline $\begin{array}{l}\text { Membuat Surat Perintah Kerja } \\
\text { (SPK) }\end{array}$ & Penulisan informasi yang tidak lengkap. & $\begin{array}{l}\text { Kesulitan ketika melakukan } \\
\text { evaluasi. }\end{array}$ \\
\hline $\begin{array}{l}\text { Melakukan pekerjaan sesuai } \\
\text { SPK }\end{array}$ & $\begin{array}{l}\text { Tidak ada pelaporan status pengerjaan } \\
\text { dari operator. }\end{array}$ & $\begin{array}{l}\text { Tidak dapat memberikan } \\
\text { informasi status pengerjaan } \\
\text { kepada customer. }\end{array}$ \\
\hline $\begin{array}{l}\text { Mengarsip Blanko Layanan, } \\
\text { SPK, dan SKR }\end{array}$ & Berkas hilang. & $\begin{array}{l}\text { Tidak ada back-up data jika } \\
\text { berkas hilang sehingga arsip } \\
\text { menjadi tidak lengkap. }\end{array}$ \\
\hline $\begin{array}{l}\text { Menyerahkan Blanko Layanan, } \\
\text { SPK, dan SKR }\end{array}$ & $\begin{array}{l}\text { Penyerahan arsip dan pelaporan } \\
\text { layanan dilakukan dalam setiap 1 } \\
\text { bulan. }\end{array}$ & $\begin{array}{l}\text { Informasi pelayanan yang } \\
\text { dilakukan tiap seksi dapat } \\
\text { diketahui setelah 1 bulan. }\end{array}$ \\
\hline
\end{tabular}

Tabel 4. Usulan Perbaikan Proses Bisnis Seksi Kemasan

\begin{tabular}{|l|l|l|}
\hline \multicolumn{1}{|c|}{ Permasalahan } & \multicolumn{1}{c|}{ Usulan } & \multicolumn{1}{c|}{ Dampak } \\
\hline $\begin{array}{l}\text { Penulisan informasi yang tidak } \\
\text { lengkap. }\end{array}$ & $\begin{array}{l}\text { Pengisian form pada sistem } \\
\text { informasi menggunakan fitur } \\
\text { "wajib diisi" }\end{array}$ & Kelengkapan informasi. \\
\hline $\begin{array}{l}\text { Tidak ada pelaporan status } \\
\text { pengerjaan dari operator. }\end{array}$ & $\begin{array}{l}\text { Status pengerjaan dilaporkan } \\
\text { dan di-update setiap hari. }\end{array}$ & $\begin{array}{l}\text { Status pengerjaan dapat } \\
\text { diinformasikan kepada customer. }\end{array}$ \\
\hline Berkas hilang. & $\begin{array}{l}\text { Pembuatan basis data secara } \\
\text { online. }\end{array}$ & Back-up data jika berkas hilang. \\
\hline $\begin{array}{l}\text { Penyerahan arsip dan } \\
\text { pelaporan layanan dilakukan } \\
\text { dalam setiap 1 bulan. }\end{array}$ & $\begin{array}{l}\text { Input data pelayanan dan status } \\
\text { pengerjaan secara online. }\end{array}$ & $\begin{array}{l}\text { Data pelayanan dan status } \\
\text { pengerjaan setiap seksi dapat } \\
\text { diterima dalam waktu yang lebih } \\
\text { cepat. }\end{array}$ \\
\hline
\end{tabular}

Terdapat 4 usulan perbaikan yaitu Pengisian form pada sistem informasi menggunakan fitur "wajib diisi", status pengerjaan dilaporkan dan di-update setiap hari, pembuatan basis data secara online dan input data pelayanan dan status pengerjaan secara online. Berdasarkan usulan perbaikan, dilanjutkan dengan pembuatan proses bisnis usulan untuk Seksi Kemasan.

\subsection{Diagram Dekomposisi}

Diagram dekomposisi menguraikan sistem ke dalam bentuk yang lebih kecil atau detail. Tingkatan teratas adalah sistem informasi pelaporan BPTTG, dan tingkatan di bawahnya menunjukkan struktur sistem informasi pelaporan BPTTG. Sistem Informasi Pelaporan BPTTG merupakan level teratas, sedangkan level di bawahnya terdapat pendaftaran akun, input data Seksi Rekayasa, dan input data Seksi Kemasan. Level yang dibawahi oleh pendaftaran akun adalah buat akun, aktivasi akun, dan login.

Level yang dibawahi oleh input data Seksi Rekayasa adalah input data biaya jasa perbengkelan, input data harga ATG, input data pekerjaan seksi rekayasa, dan buat perintah kerja seksi rekayasa. Level yang dibawahi oleh input data Seksi Kemasan adalah input data biaya jasa kemasan, input data pekerjaan seksi kemasan, dan buat perintah kerja seksi kemasan. Diagram dekomposisi sistem informasi pelaporan BPTTG ditunjukkan pada Gambar 4.

\subsection{Data Flow Diagram (DFD)}

\subsubsection{DFD Level 0}

Data Flow Diagram (DFD) merupakan diagram yang menunjukan aliran data dalam suatu sistem. Terdapat 4 entitas eksternal dalam rancangan sistem informasi pelaporan BPTTG yaitu petugas, pemesan, juru mesin / operator, dan admin / pengawas. DFD level 0 ditunjukkan pada Gambar 5.

\subsubsection{DFD Level 1}

DFD level 1 menggambarkan sistem secara lebih detail, terdapat 3 proses utama yaitu pendaftaran akun, input data seksi rekayasa dan input data seksi kemasan. DFD Level 1 ditunjukkan pada Gambar 6. 


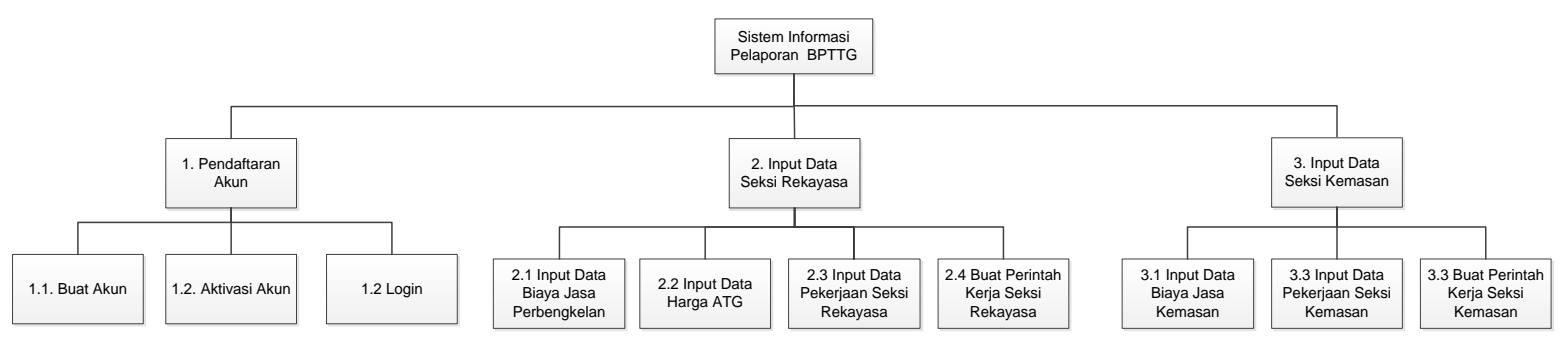

Gambar 4. Diagram Dekomposisi

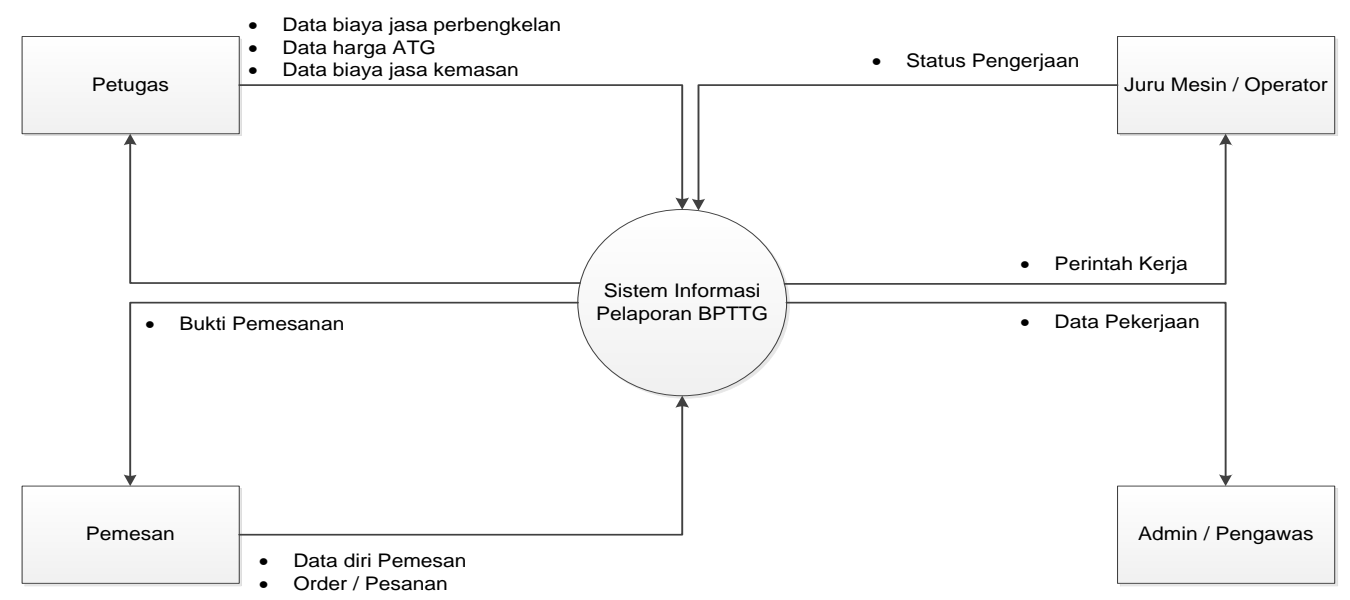

Gambar 5. DFD Level 0

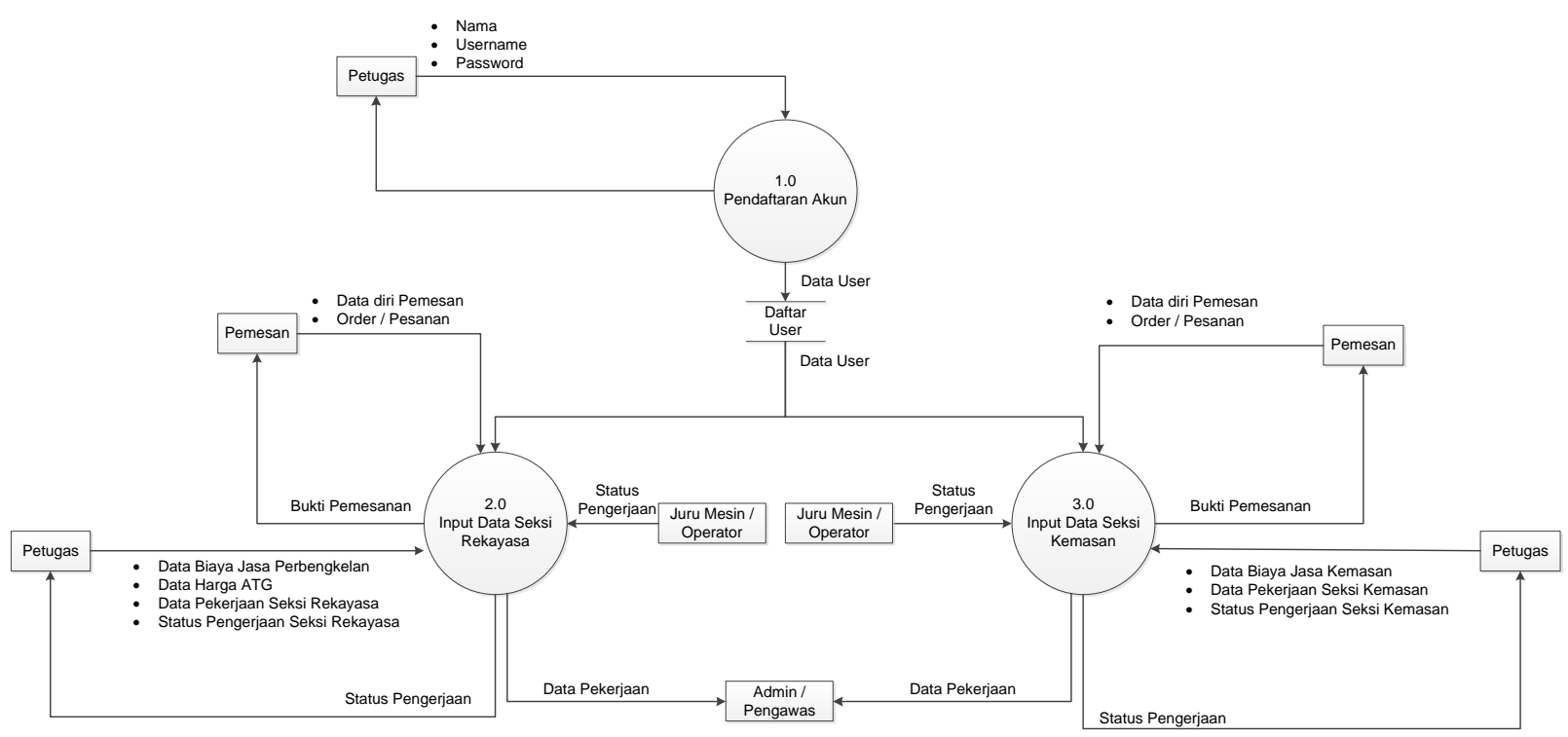

Gambar 6. DFD Level 1 


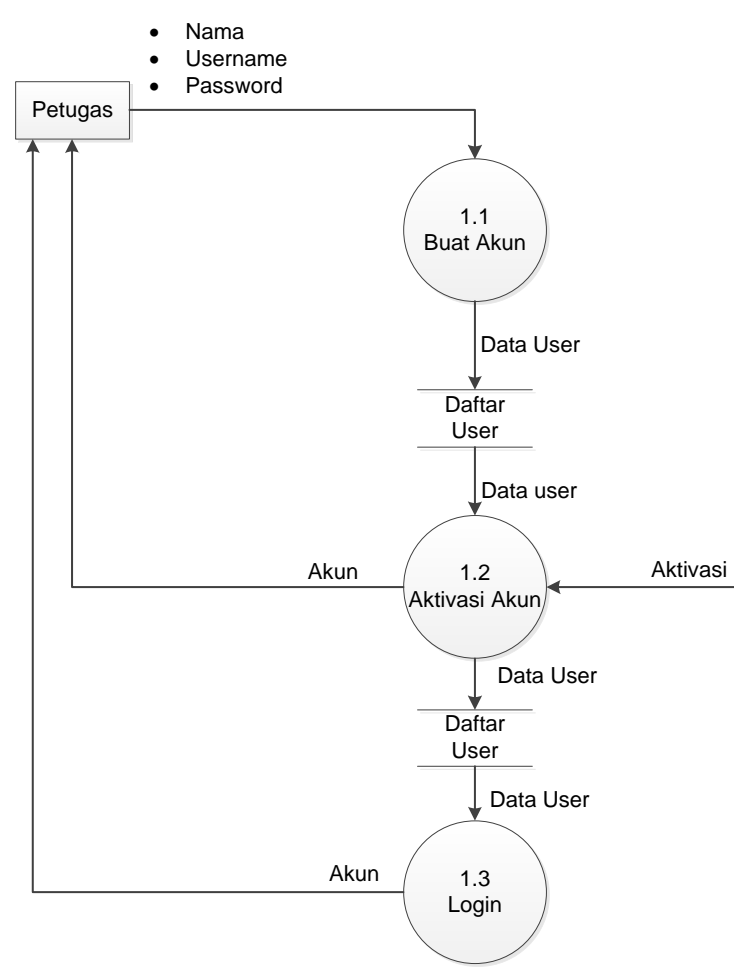

Gambar 7. DFD Level 2 (Pendaftaran Akun)

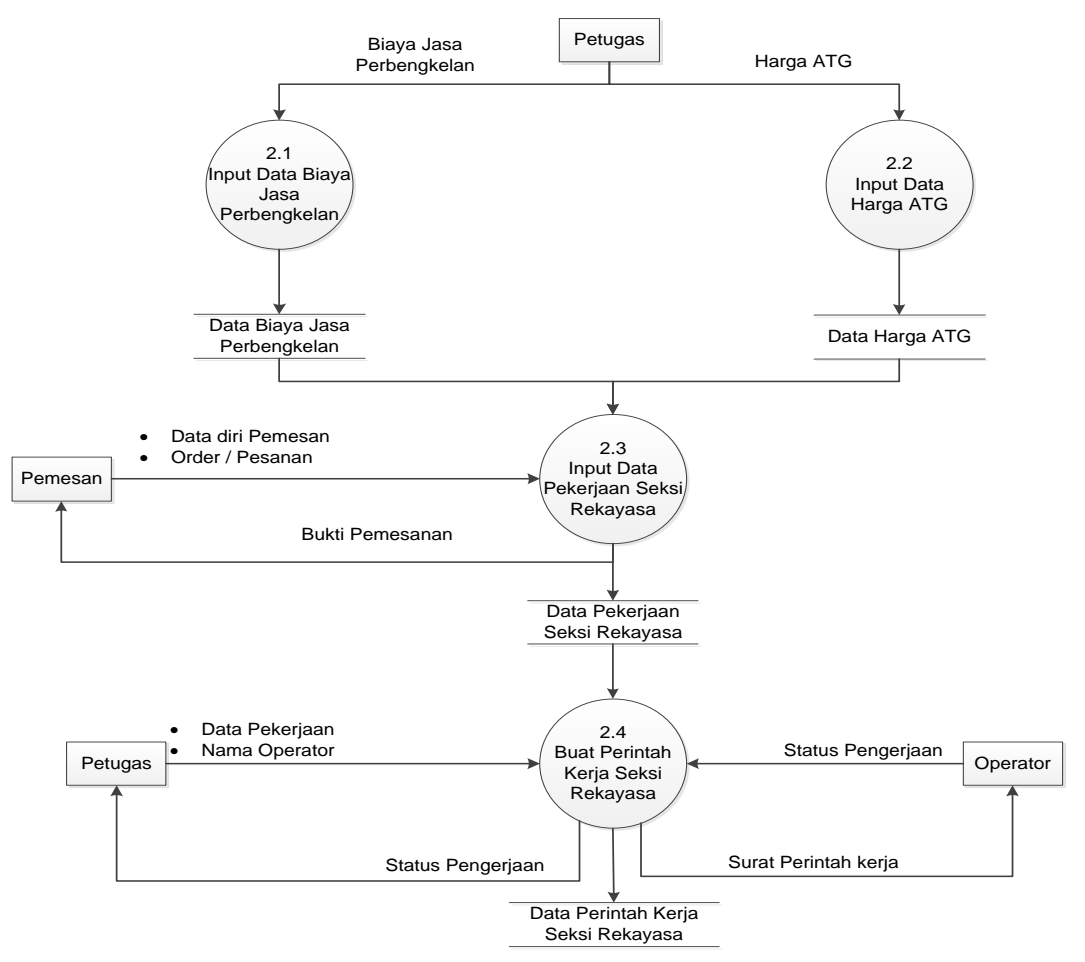

Gambar 8. DFD Level 2 (Input Data Seksi Rekayasa) 


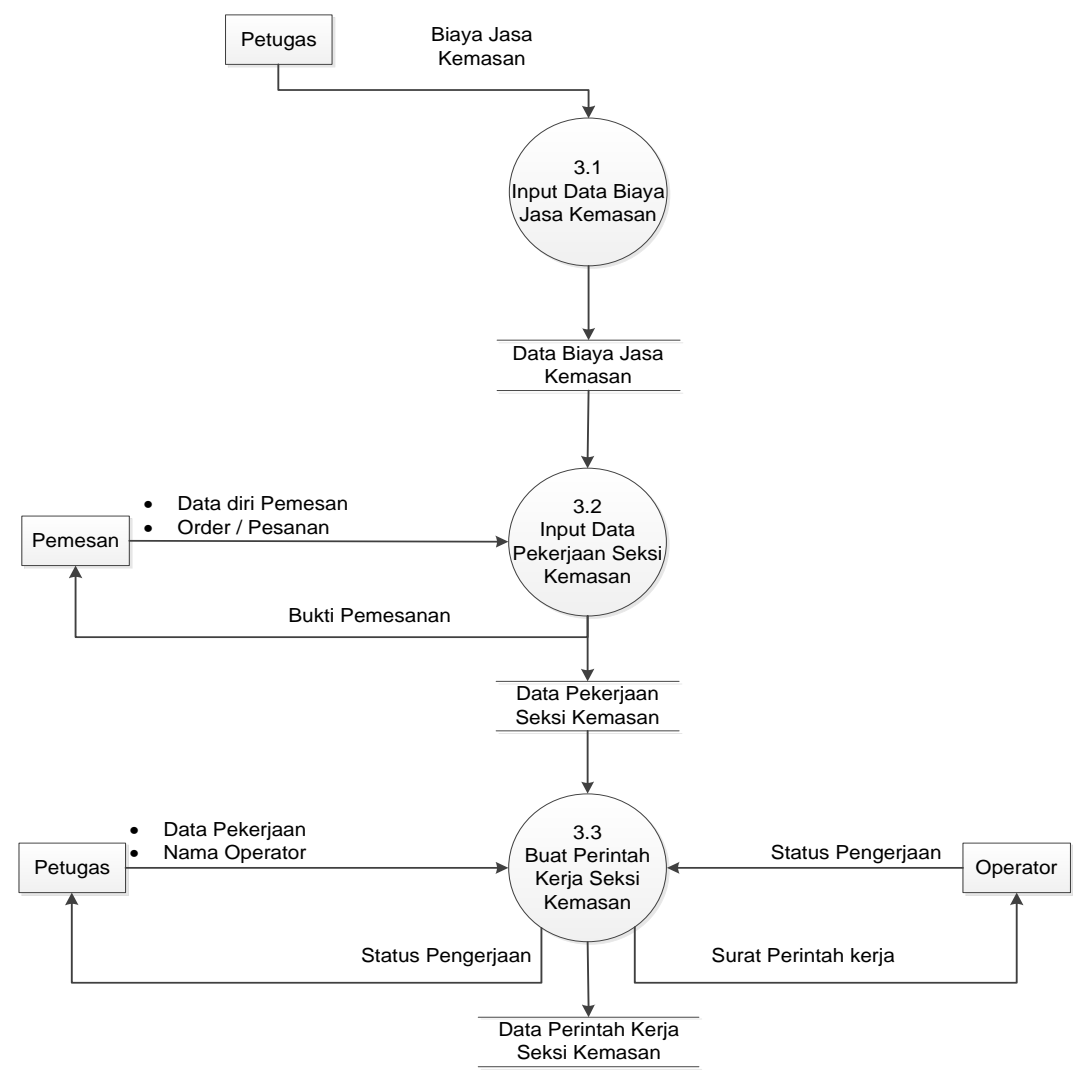

Gambar 9. DFD Level 2 (Input Data Seksi Kemasan)

\subsubsection{DFD Level 2}

DFD level 2 menggambarkan proses pendaftaran akun, proses input data Seksi Rekayasa, dan proses input data Seksi Kemasan pada DFD level 1 secara lebih detail. Proses pendaftaran akun mempunyai 3 proses yang lebih spesifik yaitu membuat akun, aktivasi akun, dan login. Akun yang telah dibuat harus diaktivasi terlebih dahulu untuk dapat mengakses sistem informasi. Aktivasi akun dapat dilakukan oleh pengguna sistem dengan role admin. Proses pendaftaran akun ditunjukkan pada Gambar 7.

Proses input data Seksi Rekayasa terdiri atas 4 proses yang lebih spesifik yaitu input data biaya jasa perbengkelan, input data harga ATG, input data pekerjaan Seksi Rekayasa, dan buat perintah kerja Seksi Rekayasa. Proses input data Seksi Rekayasa ditunjukkan pada Gambar 8.

Proses input data Seksi Rekayasa terdiri atas 3 proses yang lebih spesifik yaitu input data biaya jasa kemasan, input data pekerjaan Seksi Kemasan, dan buat perintah kerja Seksi Kemasan. Proses input data Seksi Kemasan ditunjukkan pada Gambar 9.

\subsection{Entity Relationship Diagram (ERD)}

ERD menunjukkan aliran data dan basis data berdasarkan relasi antarentitas. Kegiatan yang dilakukan adalah pemesan memesan order/pesanan ke seksi rekayasa/ seksi kemasan kemudian order/pesanan tersebut akan direkap oleh petugas di masing-masing seksi. Selanjutnya, petugas akan mengeluarkan Surat Perintah Kerja (SPK) yang diberikan kepada juru mesin/ operatordan bukti pemesanan yang diberikan kepada pemesan. Bukti pemesanan dibuat berdasarkan daftar biaya jasa perbengkelan dan harga ATG. Entity Relationship diagram ditunjukkan pada Gambar 10. 


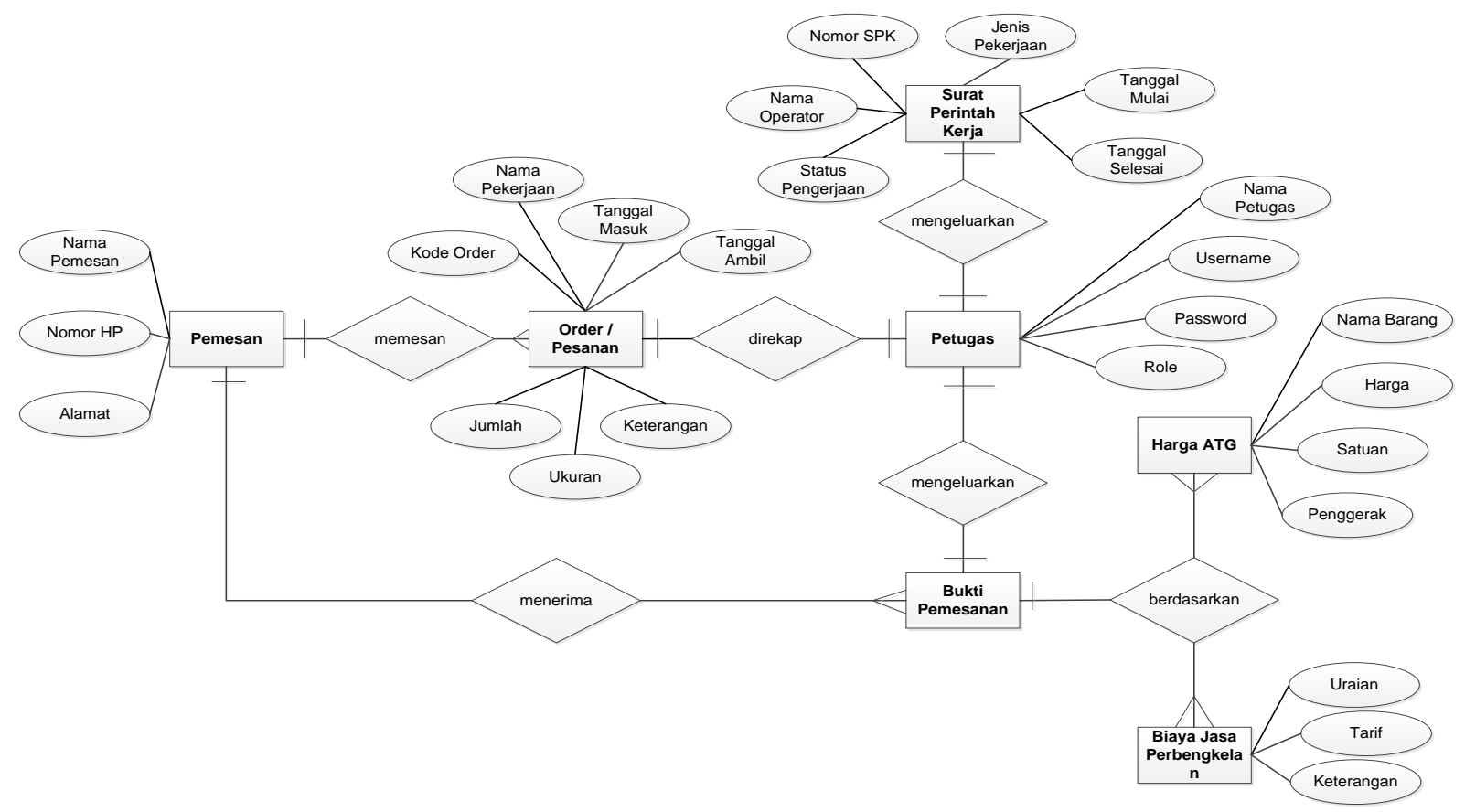

Gambar 10. Entity Relationship Diagram

\section{Sistem Informasi yang Dihasilkan}

Hasil penelitian berupa sistem informasi berbasis web. Halaman awal dari sistem informasi yaitu halaman login ditunjukkan pada Gambar 11(a). Sistem informasi memiliki 3 menu yaitu admin, seksi rekayasa, dan seksi kemasan seperti yang ditunjukkan pada Gambar 11(b). Menu admin memiliki sub-menu halaman admin (Gambar 11(c)). Halaman admin yang ditunjukkan pada Gambar 11(c) merupakan menu yang dapat diakses oleh admin dan tidak dapat diakses oleh user seksi rekayasa / user seksi kemasan. Pada halaman admin, admin dapat melakukan aktivasi akun dan menghapus akun yang terdaftar pada SI.

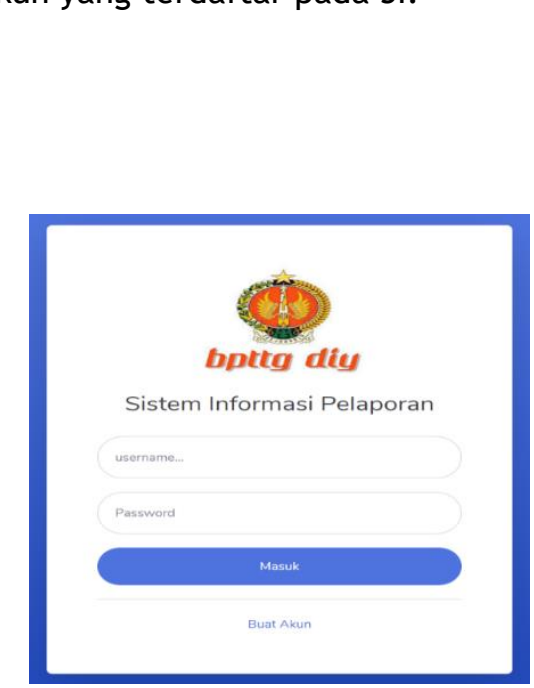

(a)

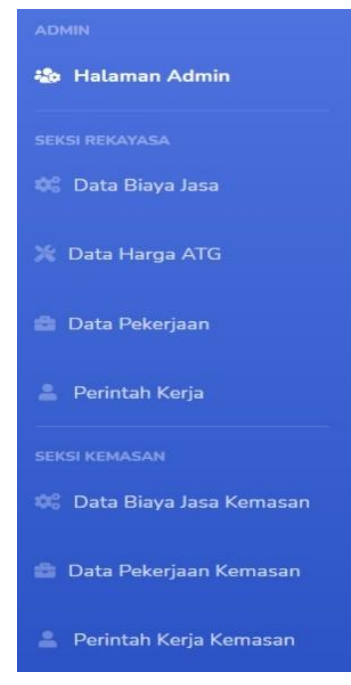

(b)

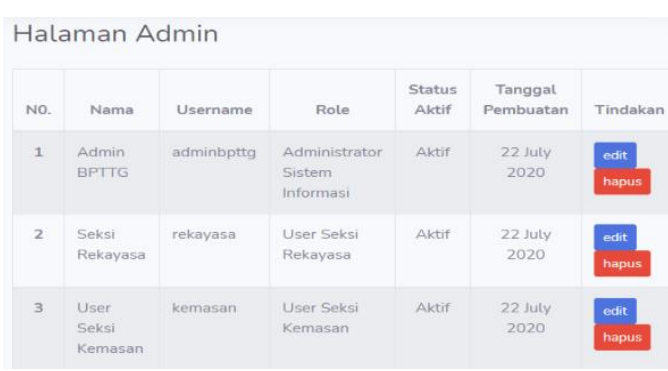

(c)

Gambar 11. Halaman utama sistem informasi: (a) halaman login, (b) halaman admin; (c) halaman sub-menu admin.

Menu-menu yang tersedia pada Seksi Rekayasa dapat dilihat pada Gambar 12. Halaman data biaya jasa pada Seksi Rekayasa yang ditunjukkan pada Gambar 12(a) menunjukkan informasi data biaya jasa perbengkelan yang disediakan oleh seksi rekayasa. Admin dapat melakukan input, edit dan hapus data biaya. Halaman data harga ATG yang ditunjukkan pada Gambar 12(b) menunjukkan 
informasi terkait Alat Tepat Guna (ATG) yang ada di seksi rekayasa. Halaman Data Pekerjaan yang ditunjukkan Gambar 12(c) menampilkan informasi terkait data pekerjaan yang diterima seksi rekayasa. User dapat melakukan input data pekerjaan jasa perbengkelan atau pembuatan ATG. User dapat menggunakan fitur edit untuk mengupdate status pengerjaan dan fitur print untuk mencetak bukti pemesanan. Halaman Data Perintah Kerja yang ditunjukkan Gambar 12(d) menampilkan informasi pesanan yang sedang atau telah selesai dikerjakan. User dapat mencetak Surat Perintah Kerja dengan fitur print. Bukti pemesanan ditunjukkan pada Gambar 12(e). SPK Seksi Rekayasa ditunjukkan pada Gambar 12(f).

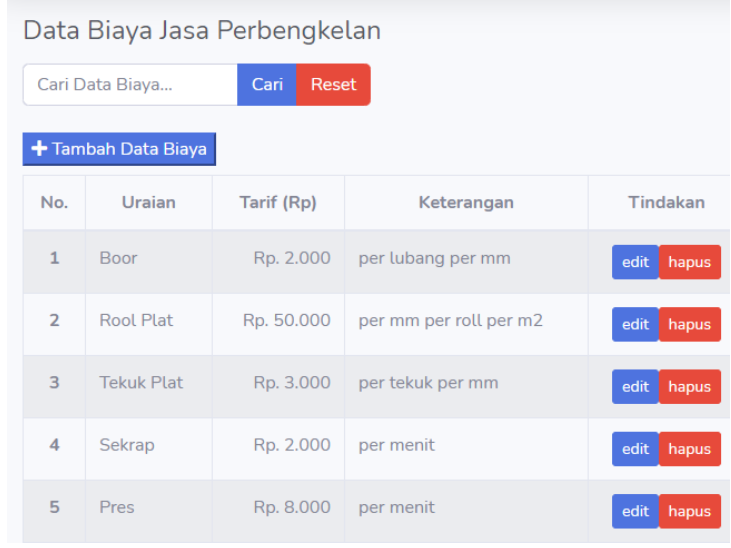

(a)

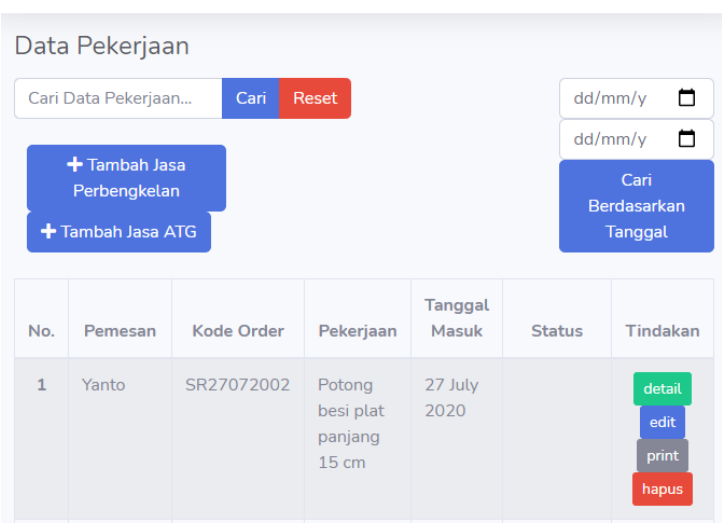

(c)

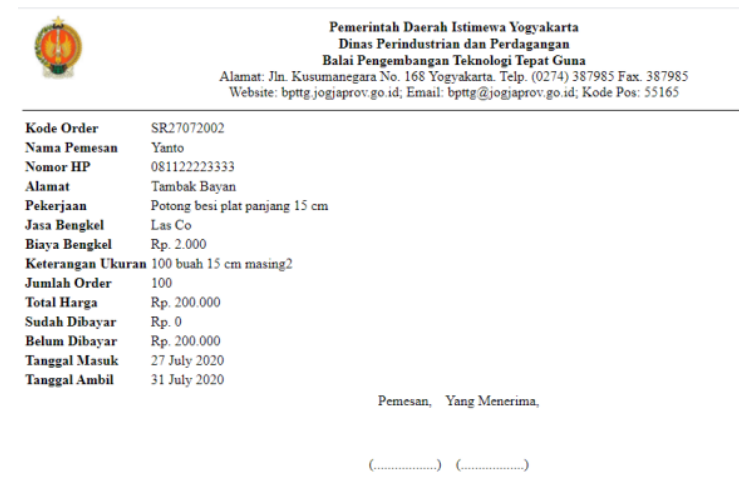

(e)

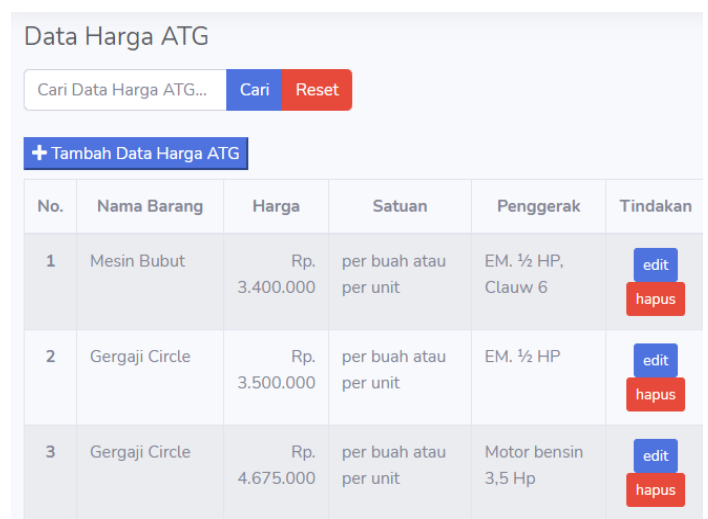

(b)

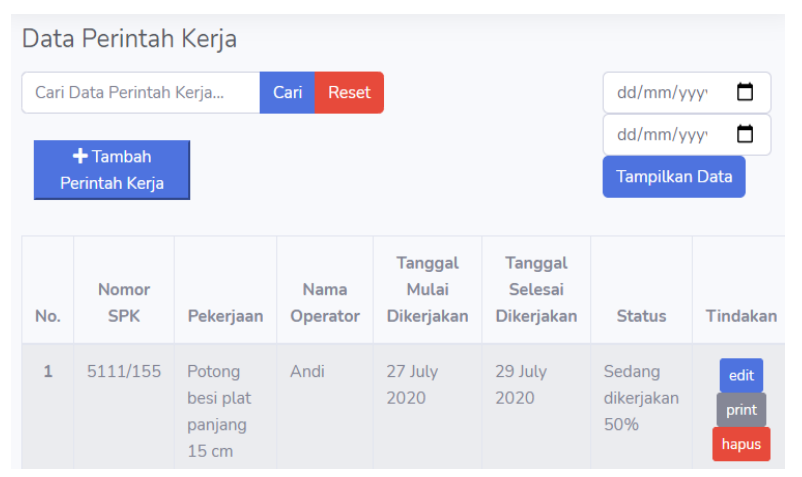

(d)

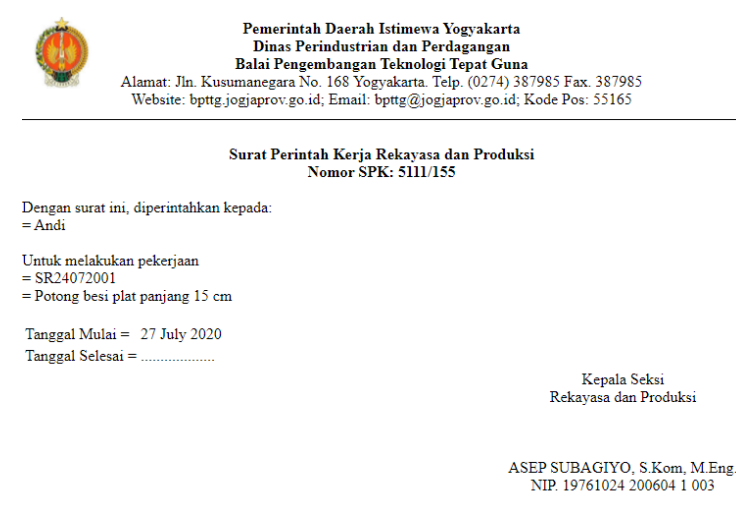

(f)

Gambar 12. Beberapa menu Seksi Rekayasa: (a) halaman data biaya jasa; (b) halaman data ATG; (c) halaman data pekerjaan; (d) halaman data perintah kerja. 
Menu-menu yang tersedia untuk Seksi Kemasan dapat dilihat pada Gambar 13. Halaman data biaya jasa kemasan pada Seksi Kemasan yang ditunjukkan pada Gambar 13(a) menunjukkan informasi data biaya jasa perbengkelan yang disediakan oleh seksi kemasan. Admin dapat melakukan input, edit dan hapus data biaya. Halaman Data Pekerjaan Kemasan yang ditunjukkan Gambar 13(b) menampilkan informasi terkait data pekerjaan yang diterima seksi kemasan. User dapat melakukan input data pekerjaan. User dapat menggunakan fitur edit untuk mengupdate status pengerjaan dan fitur print untuk mencetak bukti pemesanan. Bukti pemesanan seksi kemasan ditunjukkan pada Gambar 13(c). Halaman Data Perintah Kerja Kemasan yang ditunjukkan Gambar 13(d) menampilkan informasi pesanan yang sedang atau telah selesai dikerjakan oleh seksi kemasan. User dapat mencetak Surat Perintah Kerja dengan fitur print. SPK Seksi Kemasan ditunjukkan pada Gambar 13(e).

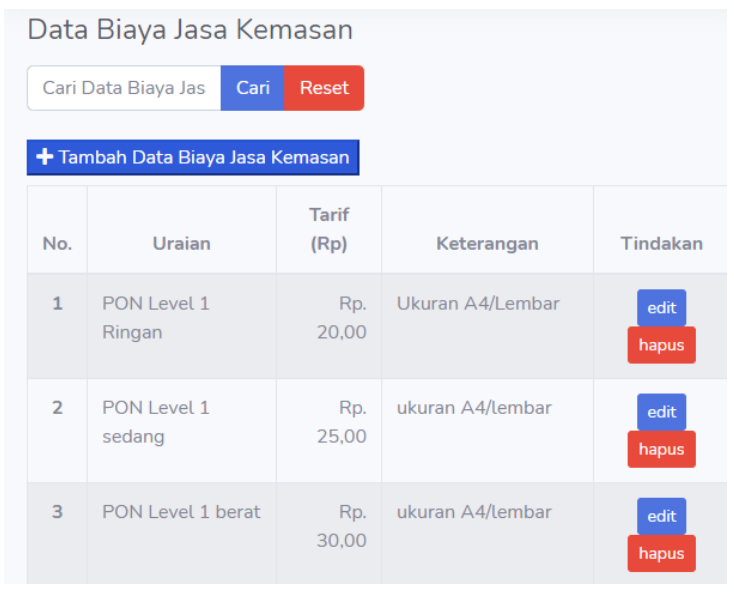

(a)

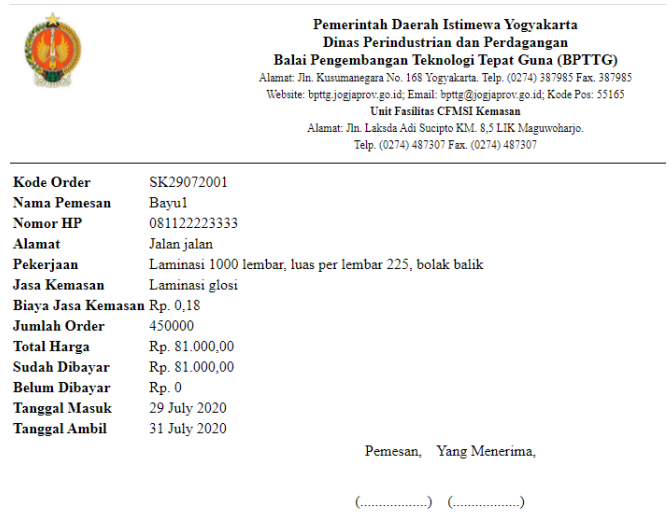

(c)

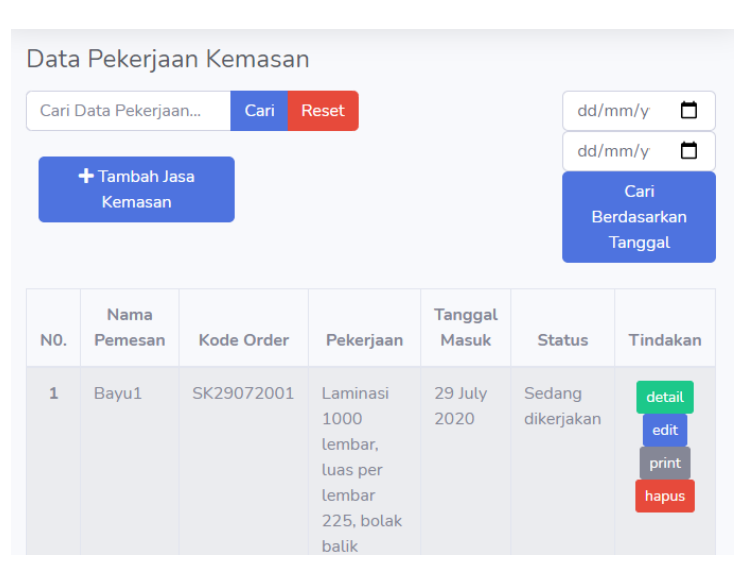

(b)

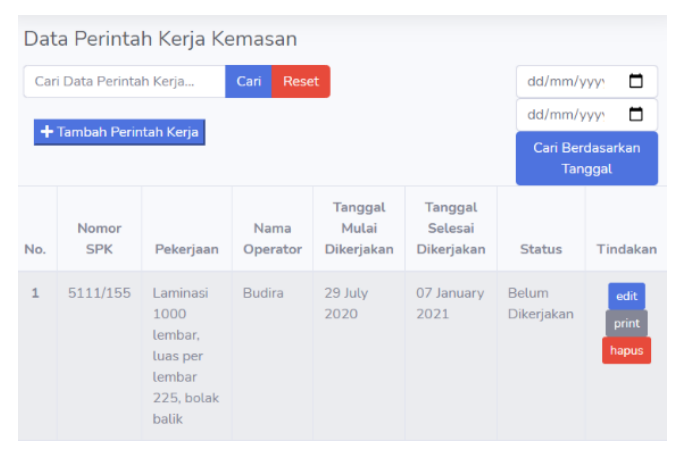

(d)

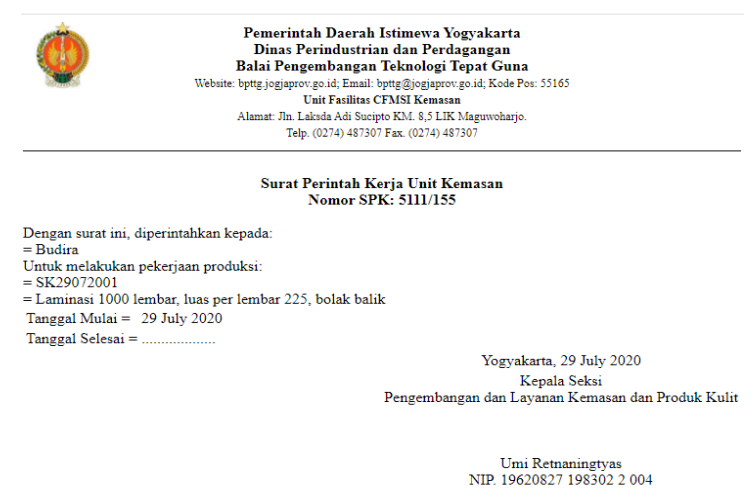

(e)

Gambar 13. Beberapa tampilan Seksi Kemasan: (a) Halaman data biaya jasa kemasan; (b) halaman data pekerjaan kemasan. 


\section{Kesimpulan}

Perancangan sistem informasi dapat mempercepat pelaporan layanan dari setiap seksi ke kantor BPTTG sehingga pelayanan yang dilakukan setiap seksi dapat dimonitor secara real-time tanpa perlu menunggu laporan bulanan dari setiap seksi yang memiliki perbedaan lokasi, yaitu Seksi Rekayasa (yang terletak di Jalan Kusumanegara \& di Jalan Sekarsuli) dan Seksi Kemasan (yang terletak di Jalan Laksda Adisucipto)

Sistem informasi dapat merekap data pelayanan yang dilakukan setiap seksi dan mempercepat pencarian terhadap informasi yang dibutuhkan seperti harga ATG, tarif jasa perbengkelan, atau status pengerjaan.

\section{Daftar Pustaka}

1. Deo, S. G. (2019). Perancangan Sistem Informasi Transaksi Order dengan Menggunakan Metode System Development Life Cycle untuk Revitalisasi UPT Ragam Metal Yogyakarta (Skripsi). Program Studi Teknik Industri, Fakultas Teknologi Industri, Universitas Atma Jaya Yogyakarta, Yogyakarta. http://e-journal.uajy.ac.id/20551/1/TI07886\%200.pdf.

2. Famsila, K. (2016). Pengembangan Sistem Informasi Manajemen Usaha Dagang $X$ (Skripsi). Program Studi Teknik Industri, Fakultas Teknologi Industri, Universitas Atma Jaya Yogyakarta, Yogyakarta. http://e-journal.uajy.ac.id/11046/1/0TI08118.pdf.

3. Hakim, I. L., \& Fitriani, L. (2016). Perancangan Sistem Informasi Laporan Surat Pertanggungjawaban Belanja Operasional di Unit Pelayanan Teknis Dinas Pendidikan Kecamatan $\begin{array}{llll}\text { Banyuresmi, Jurnal 239-245. } & \text { Algoritma, }\end{array}$ https: / /jurnal.sttgarut.ac.id/index.php/algoritma/article/view/351/318.

4. Hamzah, M. L., Purwati, A. A., Rusilawati, E., Hamzah. (2019). Rapid Application Development In Design of Library Information System In Higher Education. International Journal of Scientific \& Technology Research 8(11), 153-156. http://www.ijstr.org/final-print/nov2019/RapidApplication-Development-In-Design-Of-Library-Information-System-In-Higher-Education.pdf.

5. Ikhlas, M. (2018). Analisa dan Perancangan Sistem Informasi Transaksi dan Persediaan pada Toko Bangunan UD Romi Padang Menggunakan Bahasa Pemrograman PHP dan Database MySQL, Jurnal KomTekInfo, 5(2), 51-62. https://jkomtekinfo.org/ojs/index.php/komtekinfo/ article/view/24/34

6. Irnawati, O. \& Listianto, G. B. A. (2018). Metode Rapid Application Development (RAD) pada Perancangan Website Inventory PT. Sarana Abadi Makmur Bersama (S.A.M.B) Jakarta, Jurnal Evolusi, 6(2), https://ejournal.bsi.ac.id/ejurnal/index.php/evolusi/article/view/4414/2650.

12-18.

7. Jacka, J. M. \& Keller, P. J. (2009). Business Process Mapping : Improving Customer Satisfaction (ed. 4., pp. 33-51). US: Willey.

8. Li, R. \& Suh, A. (2015). Factors Influencing Information credibility on Social MediaPlatforms: Evidence from Facebook Pages. Procedia Computer Science 72, 314-328. https://www.sciencedirect.com/science/article/pii/S1877050915036078.

9. McKnight, D. H. \& Kacmar, C. J. (2007). Factors and Effects of Information Credibility. Proceedings of the $9^{\text {th }}$ International Conference on Electronic Commerc 2007 (ICEC 2007). https://dl.acm.org/doi/10.1145/1282100.1282180.

10. Meiryani, Sudrajat, R. (2019). Designing a Web Based Quality of Accounting Information System. International Journal of Scientific and Technology Research 8(8), 659-664. https: / / www.ijstr.org/final-print/aug2019/Designing-A-Web-based-Quality-Of-AccountingInformation-System.pdf

11. Nazir, N., dan Darmawati, G. (2018). Perancangan Pencatatan dan Pelaporan Terpadu Puskesmas Berbasis E-Report Untuk Meningkatkan Kesehatan Masyarakat, Jurnal Sains dan Teknologi, 18(2), 1-7. https://ojs.sttind.ac.id/sttind_ojs/index.php/Sain/article/view/109/90. 
12. O'Brien, J. A. \& Marakas, G. M. (2010). Management Information Systems (ed. 15, pp. 4), New York, US: McGraw-Hill/Irwin.

13. Rakasiwi, R. G. (2018). Pengembangan Sistem Informasi Terintegrasi di Ritel Nugroho (Skripsi). Program Studi Teknik Industri, Fakultas Teknologi Industri, Universitas Atma Jaya Yogyakarta, Yogyakarta. http: //e-journal.uajy.ac.id/14109/1/TI072600.pdf.

14. Tilley, S., \& Rosenblatt, H. J. (2017). System Analysis and Design (ed. 11, pp. 107-115). US: Wiley. 